\title{
The effects of rainfall intensity and rock fragment cover on soil hydrological responses in Central Chile.
}

\author{
Eduardo von Bennewitz ${ }^{1,2 *}$ Jesús Aladro ${ }^{3}$ \\ ${ }^{1}$ Universidad Austral Chile, Institute of Plant Production and Protection, Campus Isla Teja, Valdi- \\ via, Chile. ${ }^{2}$ Mendel University in Brno, Faculty of Regional Development and International Studies, \\ Trída Generála Píky 2005/7. Brno - Cerná Pole 613 00, Czech Republic. ${ }^{3}$ Universidad Católica del \\ Maule, Escuela de Agronomía. Curicó, Chile. "Corresponding author:eduardo.alvarez@mendelu.cz
}

\begin{abstract}
In Chile, $60 \%$ of the usable land is affected by erosion and the effects of rock fragment cover, however protecting the soil against these degradation processes have been sparsely studied. Understanding the effects of rainfall intensity and rock fragment cover on soil hydrological processes is a major challenge for the formulation and implementation of proper soil conservation plans. The effects of rock fragment cover on soil erosion rate, surface runoff, sediment concentration and infiltration rate were studied on a Cambisol in Central Chile using the CAZALAC rainfall simulator. Nine rainfall simulations consisting of different combinations of rainfall intensities $\left(70 \mathrm{~mm} \mathrm{~h}^{-1}, 90 \mathrm{~mm} \mathrm{~h}^{-1}\right.$, and $\left.120 \mathrm{~mm} \mathrm{~h}^{-1}\right)$ and rock fragment cover $(0 \%, 40 \%$, and $70 \%)$ were carried out. Rock fragment cover contributed to delay the time to start surface runoff and the amount surface runoff was in most of the cases directly proportional to rainfall intensity and inversely proportional to rock fragment cover percentage. Rock fragment cover reduced surface runoff in up to $72.06 \%$ in the case of the highest rainfall intensity. Final infiltration rate increased directly proportional to the percentage of rock fragment cover for each of the studied rainfall intensities. Erosion rate tended to be reduced by rock fragments $(82.2 \%$ of reduction in the case of the highest rainfall intensity and rock fragment cover), but this positive effects were not always proportional to rock fragment cover percentage. In general, lower sediment concentrations were found in covered soils (more than a tenfold reduction in the case of $120 \mathrm{~mm} \mathrm{~h}^{-1}$ rainfall intensity).
\end{abstract}

Keywords: Soil erosion, runoff generation, CAZALAC rainfall simulator, infiltration rate, sediment concentration 


\section{Introduction}

Soil hydrological processes include phenomena such as soil erosion, runoff generation, water infiltration, solute transport and water flow. Soil erosion is a major environmental concern in agricultural regions, especially in hilly areas and sloping farmlands (Wang et al., 2012) and poses a serious problem affecting the productivity of agricultural land. Soil erosion is one of the major agricultural-environmental problems in Chile too, where estimated areas of about $49.1 \%$ of the Chilean national territory and $60 \%$ of the usable land are affected by this phenomenon (CIREN, 2010; Ellies, 2000) leading to significant loss of land productive capacity (Olivares et al., 2011). Accelerated soil erosion in Chile is a consequence from unsustainable land uses (removal of vegetation cover, compaction, loss of organic matter) (Yang et al., 2015) and is also favored by the very hilly landscape and annual irregular distribution of rainfall (Ellies, 2000). In Central and South Chile 5-8\% of the annual precipitation (from 500 to $2500 \mathrm{~mm} \mathrm{y}^{-1}$ ) has a high kinetic energy and the range of erosivity oscillates between 27 and 35 Mega joule ha ${ }^{-1} \mathrm{~mm}^{-1}$ (Ellies, 2000). Rainfall intensity has been found to be one of the most important factors affecting soil erosion and surface runoff (Serrano-Muela et al., 2013), especially in the case of extreme events, which may produce high levels of soil erosion over short periods (Cerdá et al., 2016).

The surface cover of rock fragments also affects the intensity of various soil degradation processes (Wang et al., 2012). Many studies have addressed the relationship between rock fragments and soil hydrological processes such as soil erosion and runoff generation (Poesen et al., 1999; Rieke-Zapp et al., 2007; Zhang et al., 2016). Rock fragments includes particles $2 \mathrm{~mm}$ or larger in diameter with horizontal dimensions less than the size of a pedon (Miller and Guthrie, 1984). The presence of rock fragments may modify soil physical-chemical properties, affecting hydrological and erosional processes and, thus, influences plant growth (Poesen et al., 1999; Cousin et al., 2003; Wang et al., 2013). According to Poesen and lavee (1994) rock fragments may help in preserving soils in eroding environments by protecting them against raindrop impact and flow detachment, reducing the physical degradation of the eroding surface and retarding the overland flow velocity. Rock fragments increase hydraulic roughness and friction, leading to decreases in surface runoff and sediment accumulation (Rieke-Zapp et al., 2007). They also increase the macroporosity of the soil and therefore the infiltration capacity, leading to decreased soil loss and runoff $(\mathrm{Li}$ et al., 2017).

Regarding the hydrological responses, rock fragments may restrict the movement of water in the soil by reducing the cross-sectional area available for flow and by increasing the tortuosity of the medium (Zhou et al., 2011; Wang et al., 2012). They also create new voids, thereby increasing infiltration rates (Wang et al., 2012; Li et al., 2017). Rock fragment cover has been used for erosion control worldwide with contrasting results. Constantz et al. (1988) reported reduced water infiltration and increased runoff generation led by rock fragments, whereas Poesen et al. (1999), in a study at different spatial scales reported that the relationship between rock fragments and sediment production by rill erosion was negative. In a study carried out by Dadkhah and Gifford (1980), water infiltration increased with increased coverage of rock fragments on noncompacted soils, whereas water infiltration decreased on those that were compacted. Controlling soil hydrological processes and combating soil erosion under different agroecological conditions should be among the first priorities for practicing a more sustainable agriculture in the country. 
Rock fragments are local, inexpensive materials that may be easily managed and applied to control erosion. The effects of rock fragment cover on hydrological processes depend on rainfall intensity, topsoil structure and position of rock fragments (Brakensiek and Rawls, 1994), soil type, hill slope gradient, rock fragments amount and distribution among many others (Poesen et al., 1999).

According to Zhang et al. (2016), understanding of the relationship between rock fragments and soil hydrological processes remains incomplete. These authors stated that with respect to soil hydraulic conductivity, rock fragments have opposite influences: Rock fragments can restrict water flow by reducing available cross-sectional area and by increasing the tortuosity of water flow paths but also may create new preferential flow paths, increasing water infiltration. It is not clear which of the two influences is most important and whether this phenomenon is identical for all soils. Therefore in order to apply this technology it is necessary to carry out studies at a local level considering the wide variety of soils, geomorphological and climatic conditions under which agriculture is practiced in the country.

In general studies of natural resource degradation, erosion and fragility associated with rainfall erosion are scarce or have been carried out at generalized scales in Chile, due to the high cost involved (CIREN, 2010). The effects of rock fragment cover on soil hydrological processes have not been systematically studied in Chile. The lack of relevant and useful information about the factors influencing rainfall erosion, among them the effects of rock fragment cover, hinders the formulation and implementation of proper soil conservation plans (Ziadat and Taimeh, 2013).
Studying soil hydrological processes and erosion rates under natural rainfall conditions is both, timeconsuming and costly (Sheridan et al., 2008). Among the existing tools for studying erosion and surface runoff, rainfall simulators offer interesting features, especially in terms of cost effectiveness. A rainfall simulator allows generating rainfall in a controlled environment (known intensity, working pressure, duration), facilitating the assessment of superficial runoff and soil loss (Martínez-Mena et al., 2001). They may be used both under field or laboratory conditions, and among their advantages, the following may be mentioned: relatively low cost, the ability to collect data quickly and the ability to investigate many processes and treatments efficiently (Sheridan et al., 2008). Data provided by rainfall simulation and static site measurements can also be used to predict erosion rates (Sheridan et al., 2008; Martínez-Mena et al., 2001). The main disadvantage of rainfall simulation is that it takes place at a single point in time over a relatively small area and under fixed experimental conditions (Sheridan et al., 2008). In the present study, we utilized the CAZALAC simulator, developed by the Water Center for Arid and Semi-Arid Zones in Latin America and the Caribbean (CAZALAC). In Chile, it has been used mainly to study rainfall erosion at the local level and to compare distinct methods of measuring soil loss (Verbist et al., 2009; Baert, 2005). Thus, the main goal of the present study was to assess the effects of rock fragment cover and rainfall intensity on soil hydrological responses (Surface runoff, infiltration rate, soil erosion rate and sediment concentration) in Central Chile and therefore support the formulation and implementation of proper soil conservation plans. 


\section{Material and Methods}

\subsection{Study site}

The study was carried out during February and May 2014 in "Hualañe" county $\left(34^{\circ} 55^{\prime} 50.40^{\prime} \mathrm{S}, 71^{\circ}\right.$ $39^{\prime} 19.11^{\prime \prime}$ W, 240 m.a.s.1), which lies in the Curicó Province, Maule Region, Chile. The experimental study area has a Mediterranean climate (Csc according to Köppen- Geiger Climate Classification), characterized by a mean annual temperature of $17^{\circ} \mathrm{C}$ and an average annual precipitation of $700 \mathrm{~mm}$ distributed unevenly throughout the year (more than $70 \%$ is concentrated in the southern winter season), leading to a high modified Fournier index (FI) (FI between 150 and 200) and high exposure to runoff and erosion risks. The dominant land uses are pasture and forestry, carried out in steep slopes. The site is located on the slope of a gradient $>20 \%$ and the soil thickness ranges from $20-85 \mathrm{~cm}$. The soil at the site was a loam: $20 \%$ clay $(<2 \mu \mathrm{m}), 44 \%$ of sand $(20-2000 \mu \mathrm{m})$ and $36 \%$ of silt $(2-50 \mu \mathrm{m})$ that belongs to the "Hualañe" soil series (Typic Xerochrepts, Cambisol) (Casanova et al., 2007). Dry bulk density: $1.4 \mathrm{~g} \mathrm{~cm}^{-3}$. The soil moisture retention curve $(0-0.20 \mathrm{~m})(\mathrm{pF}$ curve) gave the following results for $\mathrm{pF}$-values: $\mathrm{pF} 2.5=21 \% \mathrm{v} / \mathrm{v}$, $\mathrm{pF} 4.2=10 \% \mathrm{v} / \mathrm{v}$, initial water content: $11 \% \mathrm{v} / \mathrm{v}$. Soil chemical analysis: $\mathrm{Ca}\left(8.9 \mathrm{cmol}_{\mathrm{c}} \mathrm{kg}^{-1}\right), \mathrm{Mg}(1.3 \mathrm{cmolc}$ $\left.\mathrm{kg}^{-1}\right), \mathrm{K}\left(300 \mathrm{mg} \mathrm{kg}^{-1}\right), \mathrm{Na}\left(100 \mathrm{mg} \mathrm{kg}{ }^{-1}\right)$, CEC (16.2 cmolc $\mathrm{kg}^{-1}$ ), O.M (2.4\%), pH-H $\mathrm{O}$ (6.0). The soil was air-dried, crushed and then sieved to pass a $5-\mathrm{mm}$ screen. Granitic (Andesite) rock fragments of irregular shape with sizes ranging from $30 \mathrm{~mm}$ to $40 \mathrm{~mm}$ were collected from the study site. Rock fragments were uniformly distributed over the plot boxes. Three different rock fragment covers (area covered by rock fragments) were tested $(0 \%, 40 \%$, and $70 \%)$.

The experiments were conducted in three parallel $1.0 \mathrm{~m} \times 0.5 \mathrm{~m}$ plot boxes, $2.2 \%$ slope, delineated using steel plates and built on the selected study site. A funnel was incorporated in the lower part of the plot boxes for assessing soil erosion and overland flow after the simulated rainfall. The bottom of the box consisted of a bed in which the perforated drains were located. The first layer $(0.0 \mathrm{~m}-0.2 \mathrm{~m})$ was filled with sand to facilitate drainage. The subsequent layer from $0.2 \mathrm{~m}$ to $0.4 \mathrm{~m}$ was packed with sieved soil from the study site. The last layer consisted of the different rock fragment covers $(0 \%, 40 \%$, and $70 \%)$.

\subsection{Rainfall simulation}

Artificial rainfall was distributed over the study plots using a CAZALAC rainfall simulator (CAZALAC, 2004). The simulator consists of a continuous sprinkler system with pressurized water supported by four mobile, metallic tripods with adjustable legs (Sangüeza et al., 2010; Baert, 2005) (Figure 1).

Pipes are made from polyvinyl chloride (PVC), 32 $\mathrm{mm}$ diameter. The sprinkler consists of four Teejet full-cone sprinkler spray nozzles (model TG-SS14W, Spraying Systems Co., Wheaton, Illinois, USA) that produce an axial flow, wide-angle, full spray cone (Baert, 2005). Sprinklers were located on a straight line and spaced at $1 \mathrm{~m}$ from each other. Drop size and the velocity at the nozzle outlet may be controlled by regulating the working pressure (pressure regulation valve), which is also controlled by two manometers (located one in the front and the other at the end of the system). The simulator was mounted $2 \mathrm{~m}$ above the soil surface. Water was supplied by a 10001 water tank connected to the sprinkler system through an elbow and fast closing cutoff valves. The pressure was provided by a dual pump with a $30.5 \mathrm{~cm} 3$ cylinder and $1 \mathrm{~kW}$ power. To mitigate the effects of the wind on the erosive characteristics of simulated rainfall a polyethylene mesh with $65 \%$ shade was placed in the plot area. 


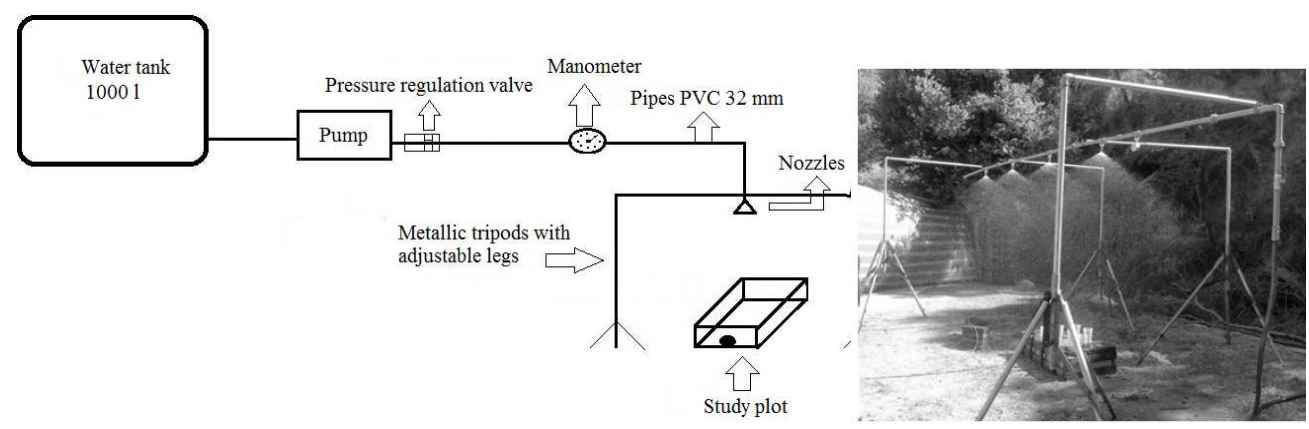

Figure 1. Diagram and layout of the CAZALAC rainfall simulator and study plots.

\subsection{Calibration}

Different working pressures were tested before using the simulator on the field. The pressure that provided the most homogenous distribution and wet radius in the absence of wind was $100 \mathrm{kpa}$. Median drop size was $2.2 \mathrm{~mm}$ and wet radius was approximately $1.6 \mathrm{~m}$. Rainfall uniformity was controlled using the Christiansen's uniformity coefficient (CU) of 121 containers, distanced $15 \mathrm{~cm}$ each other, and placed on a uniformly spaced grid $(1.5 \mathrm{~m} \times 1.5 \mathrm{~m})$.

$\mathrm{CU}=100 \times\left(1-\frac{\sum_{\mathrm{i}=1}^{\mathrm{n}}\left(\mathrm{X}_{\mathrm{i}}-\overline{\mathrm{X}}\right)}{\sum_{\mathrm{i}=1}^{\mathrm{n}} \mathrm{X}_{\mathrm{i}}}\right)$

Where:

$\mathrm{X}$ is the height of the water registered for each container.

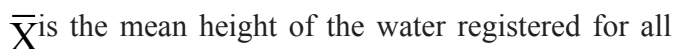
containers.

Mean rainfall uniformity was $85 \pm 2.2 \%$. These values are considered acceptable according to MartínezMena et al. (2001).

\subsection{Rainfall simulation}

Nine rainfall simulations, consisting of different combinations of rainfall intensities $\left(70 \mathrm{~mm} \mathrm{~h}^{-1}, 90 \mathrm{~mm}\right.$ $\mathrm{h}^{-1}$, and $\left.120 \mathrm{~mm} \mathrm{~h}^{-1}\right)$ and rock fragment covers $(0 \%$, $40 \%$, and $70 \%$ ) were carried out in three plot boxes $(1.0 \mathrm{~m} \times 0.5 \mathrm{~m})$ (each of them was a repeat). Rainfall was then applied for 16 min with a working pressure of $100 \mathrm{kpa}$. After each simulation, rock fragments were removed and recollected to realize the next configuration. Surface runoff was recorded after simulated rainfall events in flasks connected with a funnel incorporated in the lower part of the plot boxes. Surface runoff volume was collected and measured at 2 min intervals for each of the nine rainfall simulations. Collected surface runoff samples from the flasks were filtered during $24 \mathrm{~h}$ to remove the water. Remaining sediment was oven-dried $\left(105^{\circ} \mathrm{C}\right)$ for $24 \mathrm{~h}$ and then weighed to determine dry sediment mass (Da Rocha et al., 2016). The ratio of dry sediment mass to runoff volume represents the sediment concentration $\left(\mathrm{g} \mathrm{L}^{-1}\right)$. Erosion rate was calculated as the sediment yield per unit erosion rate $\left(\mathrm{g} \mathrm{m}^{-2} \mathrm{~min}^{-1}\right)$ according to the methodology of Wang et al. (2012). A drainage collector was placed at the base of the plot boxes for collecting and measuring infiltrated water.

\subsection{Data analysis}

The data was normally distributed. Results were subject to two-way analysis of variance (ANOVA) and mean separation was done by Duncan's multiple range 
test at $5 \%$ level of significance to determine significant differences among treatments.
Statistical procedures were performed using JMP 10 (SAS software).

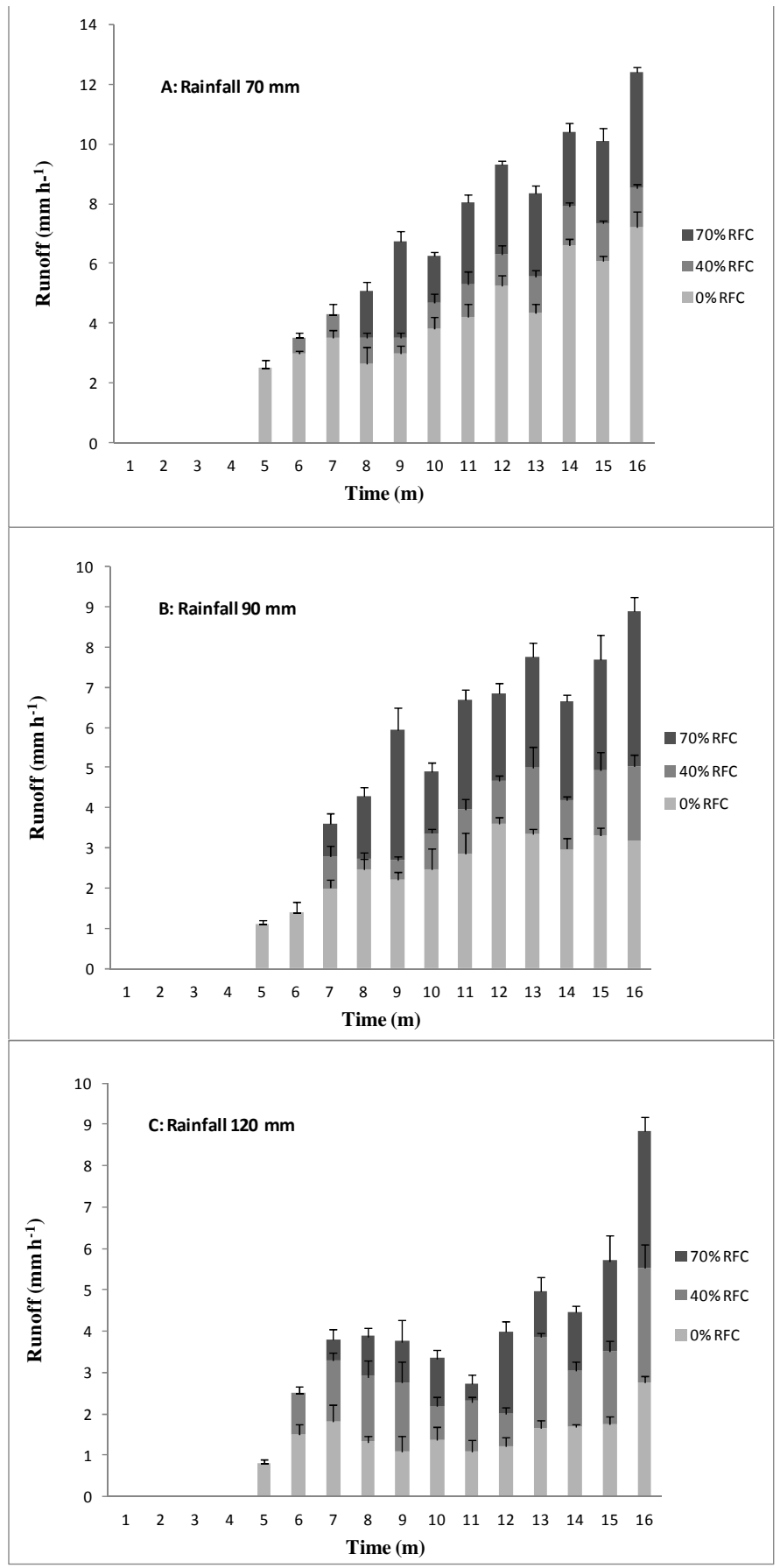

Figure 2. Time to start surface runoff for three different rock fragment covers (RFC) and three rainfall intensities $\left(\mathrm{A}: 70 \mathrm{~mm} \mathrm{~h}^{-1}\right.$, $\mathrm{B}: 90 \mathrm{~mm} \mathrm{~h}^{-1}$ and $\left.120 \mathrm{~mm} \mathrm{~h}^{-1}\right)$. 


\section{Results}

\subsection{Surface runoff}

In our study, the beginning of surface runoff tended to be influenced by rock fragment cover but not by rainfall intensity (Figure 2).

The time to start surface runoff varied between 5 and 7 min under different rock fragment covers and rainfall intensities. When the rock fragment cover increased, the time to start surface runoff was retarded. Runoff started quickly in the case of bare soils and tended to be delayed up to two minutes in soils with $70 \%$ rock fragment cover. The runoff rate increased rapidly at the beginning of the first 5-8 min of simulated rainfall for the different rock fragment cover classes and rainfall intensities and then tended to increase and decrease al- ternately in the range between 8 and $16 \mathrm{~min}$ in the case of the soils with $40 \%$ and $70 \%$ rock fragment cover.

Observed results indicate that surface runoff was, in most of the cases, directly proportional to rainfall intensity and inversely proportional to rock fragment cover (Table 1). The minimum values for runoff were observed in the case of $70 \%$ rock fragment cover and $70 \mathrm{~mm} \mathrm{~h}^{-1}$ rainfall intensity and the maximum value was observed for $0 \%$ rock fragment cover and $120 \mathrm{~mm}$ $\mathrm{h}^{-1}$ rainfall intensity. From the results depicted in table 1 , it can be stated that bare soils are generally more susceptible to surface runoff than soils with rock fragment cover. Compared with bare soils, rock fragment covers of $40 \%$ and $70 \%$ reduced surface runoff by 0 and $48.4 \%$ in the case of $70 \mathrm{~mm} \mathrm{~h}^{-1}$ rainfall intensity, and $28.8 \%$ and $72.06 \%$ in the case of $120 \mathrm{~mm} \mathrm{~h}^{-1}$ rainfall intensity.

Table 1. Effects of rainfall intensity and rock fragment cover on surface runoff $\left(\mathrm{mm} \mathrm{h}^{-1}\right)$.

\begin{tabular}{lccc}
\hline Rainfall intensity & \multicolumn{3}{c}{ Rock fragment cover (\%) } \\
\cline { 2 - 4 }$\left(\mathrm{mm} \mathrm{h}^{-1}\right)$ & 0 & 40 & 70 \\
\hline 70 & $11.36 \pm 1.82 \mathrm{e}$ & $11.36 \pm 1.82 \mathrm{e}$ & $5.86 \pm 0.37 \mathrm{f}$ \\
90 & $17.10 \pm 0.35 \mathrm{~cd}$ & $19.01 \pm 0.25 \mathrm{c}$ & $13.78 \pm 0.55 \mathrm{de}$ \\
120 & $36.73 \pm 3.24 \mathrm{a}$ & $26.14 \pm 1.04 \mathrm{~b}$ & $10.26 \pm 1.26 \mathrm{e}$ \\
\hline
\end{tabular}

Different letters within a row and column indicate significant differences at the $5 \%$ level.

Regarding the effect of rock fragments in reducing runoff, it seems that its efficiency depends on rainfall intensity (Table 1, Figure 3). For example for rainfall intensities of $70 \mathrm{~mm} \mathrm{~h}^{-1}$ and $90 \mathrm{~mm} \mathrm{~h}^{-1}$, a significant reduction of surface runoff with respect to bare soils was observed only in the case of $70 \%$ of rock fragment cover. In the case of $120 \mathrm{~mm}$ rainfall, both rock fragment covers $(40 \%$ and $70 \%)$ were effective for reducing runoff in comparison to bare soil. The positive effects of rock fragment cover on reducing surface runoff were also evident in the fact that soils with greater rock fragment cover, for each rainfall intensity, tended to show higher infiltration rates (Table 2). 


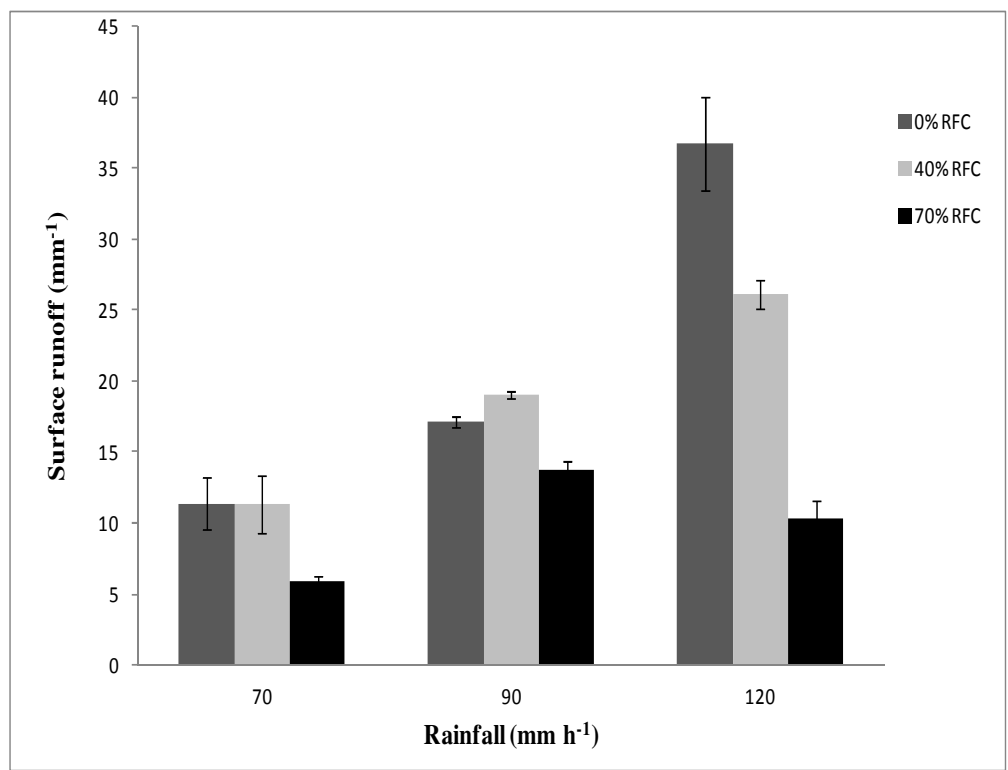

Figure 3. Cumulative surface runoff for the time of 16 minutes, for the three different rainfall intensities $(70 \mathrm{~mm}$ $\mathrm{h}^{-1}, 90 \mathrm{~mm} \mathrm{~h}^{-1}$ and $\left.120 \mathrm{~mm} \mathrm{~h}^{-1}\right)$ and rock fragment covers $(0 \%, 40 \%$, and $70 \%)$.

\subsection{Infiltration rate}

The positive effects of rock fragment cover on reducing surface runoff show that soils with greater rock fragment cover are more readily infiltrated. This is confirmed by the final infiltration rate assessment. In our study final infiltration rate increased directly proportional to the percentage of rock fragment cover for each of the studied rainfall intensities (Table 2).
The minimum values for final infiltration rate were observed in the case of bare soils and $70 \mathrm{~mm} \mathrm{~h}^{-1}$ rainfall intensity and the maximum value was observed for $70 \%$ rock fragment cover and $120 \mathrm{~mm} \mathrm{~h}^{-1}$ rainfall intensity. Compared with bare soils, rock fragment covers of $40 \%$ and $70 \%$ increased final infiltration rate by $16.5 \%$ and $24.3 \%$ respectively in the case of $70 \mathrm{~mm} \mathrm{~h}^{-1}$ and $24.9 \%$ and $32.3 \%$ respectively in the case of $120 \mathrm{~mm} \mathrm{~h}^{-1}$ rainfall intensity.

Table 2. Effects of rainfall intensity and rock fragment cover on final infiltration rate $\left(\mathrm{mm} \mathrm{h}^{-1}\right)$.

\begin{tabular}{lccc}
\hline Rainfall intensity & \multicolumn{3}{c}{ Rock fragment cover (\%) } \\
\cline { 2 - 4 }$\left(\mathrm{mm} \mathrm{h}^{-1}\right)$ & 0 & 40 & 70 \\
\hline 70 & $47.30 \pm 3.60 \mathrm{~h}$ & $55.10 \pm 1.90 \mathrm{~g}$ & $58.80 \pm 1.40 \mathrm{fg}$ \\
90 & $62.80 \pm 2.70 \mathrm{ef}$ & $66.20 \pm 1.70 \mathrm{de}$ & $72.40 \pm 2.00 \mathrm{~cd}$ \\
120 & $75.80 \pm 2.30 \mathrm{c}$ & $94.73 \pm 1.22 \mathrm{~b}$ & $100.30 \pm 3.70 \mathrm{a}$ \\
\hline
\end{tabular}

Different letters within a column indicate significant differences at the $5 \%$ level. 


\subsection{Erosion rate}

The rock fragment cover on the soil surface significantly reduced erosion rate in the case of $90 \mathrm{~mm} \mathrm{~h}^{-1}$ and $120 \mathrm{~mm} \mathrm{~h}^{-1}$ rainfall intensities but not in the case of $70 \mathrm{~mm} \mathrm{~h}^{-1}$ (Table 3, Figure 4). At high rainfall intensity $\left(120 \mathrm{~mm} \mathrm{~h}^{-1}\right), 70 \%$ rock fragment cover reduced erosion rate from $3.98 \mathrm{~g} \mathrm{~m}^{-2} \mathrm{~min}^{-1}$ to a negligible value of $0.71 \mathrm{~g} \mathrm{~m}^{-2} \mathrm{~min}^{-1}$ (82.2\% of reduction). Even at $40 \%$ rock fragment cover a significant reduction compared with bare soils was observed. Erosion rate was reduced by rock fragment cover only in case of $90 \mathrm{~mm}$ $\mathrm{h}^{-1}$ and $120 \mathrm{~mm} \mathrm{~h}^{-1}$ rainfall intensities (Table 3) and $40 \%$ rock fragment cover did not differ significantly in terms of erosion rate reduction compared with $70 \%$ rock fragment cover.

Table 3. Effects of rainfall intensity and rock fragment cover on erosion rate $\left(\mathrm{g} \mathrm{m}^{-2} \mathrm{~min}^{-1}\right)$.

\begin{tabular}{lccc}
\hline Rainfall intensity & \multicolumn{3}{c}{ Rock fragment cover (\%) } \\
\cline { 2 - 4 }$\left(\mathrm{mm} \mathrm{h}^{-1}\right)$ & 0 & 40 & 70 \\
\hline 70 & $1.29 \pm 1.82 \mathrm{~cd}$ & $0.97 \pm 0.25 \mathrm{~cd}$ & $0.62 \pm 0.21 \mathrm{~d}$ \\
90 & $2.56 \pm 0.27 \mathrm{~b}$ & $1.85 \pm 0.13 \mathrm{c}$ & $1.59 \pm 0.75 \mathrm{~cd}$ \\
120 & $3.98 \pm 0.76 \mathrm{a}$ & $1.14 \pm 0.12 \mathrm{~cd}$ & $0.71 \pm 0.16 \mathrm{~cd}$ \\
\hline
\end{tabular}

Different letters within a row and column indicate significant differences at the $5 \%$ level.

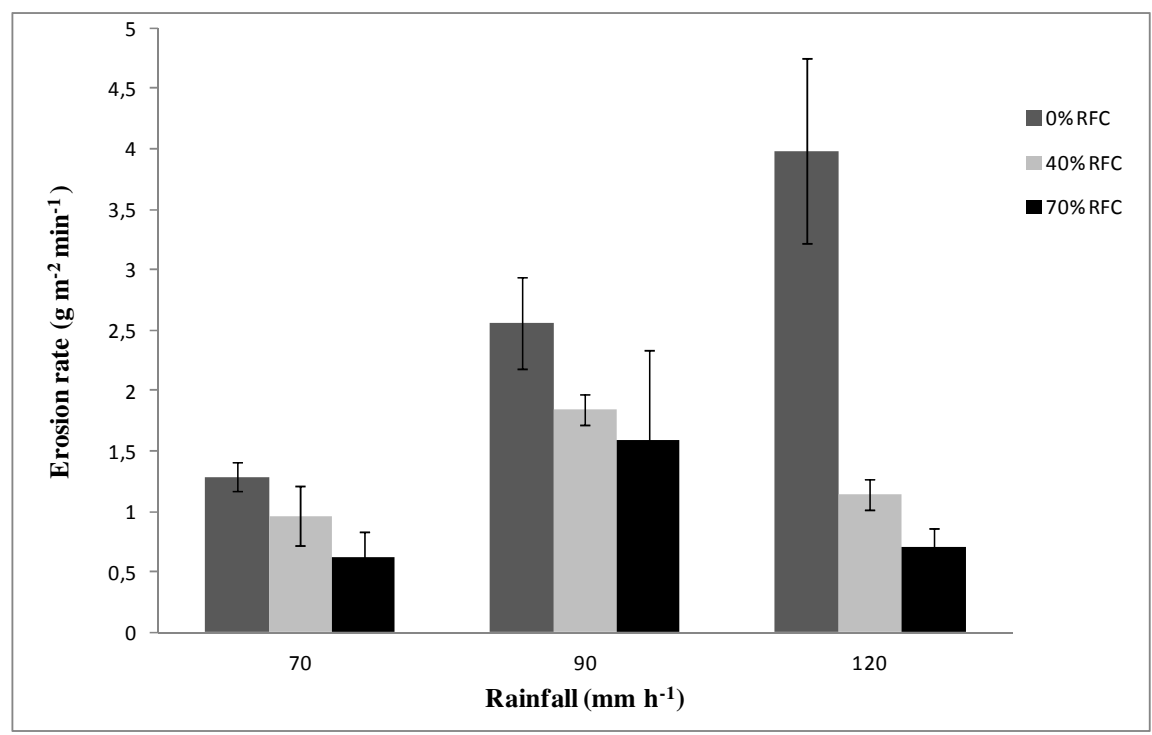

Figure 4. Erosion rate at three different rainfall intensities $\left(70 \mathrm{~mm} \mathrm{~h}^{-1}, 90 \mathrm{~mm} \mathrm{~h}^{-1}\right.$ and $\left.120 \mathrm{~mm} \mathrm{~h}^{-1}\right)$ and rock fragment covers (RFC $0 \%, 40 \%$, and $70 \%$ ). 


\subsection{Sediment concentration}

In general, lower sediment concentrations, for different rainfall intensities, were found in covered soils (Table 4). Sediment concentrations were strongly reduced from $20.6 \mathrm{~g} \mathrm{~L}^{-1}$ in the case of bare soil to only $2.09 \mathrm{~g} \mathrm{~L}^{-1}$ at $120 \mathrm{~mm} \mathrm{~h}^{-1}$ rainfall intensity. This means more than a tenfold reduction.

In the cases of lower rainfall intensities, the reduction was not as dramatic, but equally effective. $51 \%$ and $85 \%$ reduction in the case of 40 and $70 \%$ rock fragment cover at $70 \mathrm{~mm} \mathrm{~h}^{-1}$ rainfall intensity and $56.7 \%$ and $74.3 \%$ of reduction in the case of 40 and $70 \%$ rock fragment cover at $120 \mathrm{~mm} \mathrm{~h}^{-1}$ rainfall intensity.

Table 4. Effects of rainfall intensity and rock fragment cover on sediment concentration $\left(\mathrm{g} \mathrm{L}^{-1}\right)$.

\begin{tabular}{lccc}
\hline Rainfall intensity & \multicolumn{3}{c}{ Rock fragment cover (\%) } \\
\cline { 2 - 4 }$\left(\mathrm{mm} \mathrm{h}^{-1}\right)$ & 0 & 40 & 70 \\
\hline 70 & $3.44 \pm 0.42 \mathrm{bc}$ & $1.69 \pm 0.39 \mathrm{bc}$ & $0.51 \pm 0.18 \mathrm{c}$ \\
90 & $7.01 \pm 2.18 \mathrm{~b}$ & $3.03 \pm 0.01 \mathrm{bc}$ & $1.80 \pm 0.81 \mathrm{bc}$ \\
120 & $20.60 \pm 5.38 \mathrm{a}$ & $2.49 \pm 0.34 \mathrm{bc}$ & $2.09 \pm 1.17 \mathrm{bc}$ \\
\hline
\end{tabular}

Different letters within a column indicate significant differences at the $5 \%$ level.

\section{Discussion}

\subsection{Surface runoff}

Our findings agree with the results of Poesen et al. (1990), Cerdá (2001) and Wang et al. (2012), who demonstrated that both surface runoff and infiltration were affected by rock fragment cover. Our results also agree with those presented by Wang et al. (2012), regarding the delay in the initiation of surface runoff produced by increasing rock fragment cover area, regardless of rainfall intensity. This decrease and delay on initiation of surface runoff can be attributed to increased soil surface roughness, reduced crosssectional area and increased tortuosity produced by rock fragments on the soil surface (Van Wesemael et al., 1996; Cerdá, 2001; Wang et al., 2012), which in turn increases detention of surface runoff. According to Rieke-Zapp et al. (2007), rock fragments increase hydraulic roughness and friction, leading to decreases in surface runoff and sediment accumulation. They also increase the macroporosity of the soil and therefore the infiltration capacity, leading to decreased soil loss and runoff (Li et al., 2017). Regarding the hydrological responses, rock fragments may restrict the movement of water in the soil by reducing the crosssectional area available for flow and by increasing the tortuosity of the medium (Zhou et al., 2011; Wang et al., 2012).

\subsection{Infiltration rate}

Regarding the infiltration rates, our results agree with those reported by Martínez-Zavala and Jordán (2008), which stated that the increase in hydraulic roughness and interception produced by rock fragments in the soil surface, decrease surface runoff, increasing therefore the infiltration rate. The role of rock fragments 
as a regulator of runoff and infiltration rate has also been recognized by authors, such as Martínez-Zavala and Jordán (2008) and Martínez-Zavala et al. (2010). According to Wang et al. (2012), rock fragments, besides reducing the cross-sectional area and increasing the tortuosity, create new voids, thereby increasing infiltration rates in the soil. The effects of rock fragment on infiltration rates also depend on the type and structure of the soil and the type and position of the rock fragments (Brakensiek and Rawls, 1994; Poesen et al., 1990; Rieke-Zapp et al., 2007). If rock fragments lay on the soil surface, the effect is positive but is negative if the rock fragments are embedded in the soil.

\subsection{Erosion rate}

Rock fragments provided a protective cover over the soil surface, reducing the impact of raindrops and the area subject to the eroding forces of surface water flow (Posen 1999; Zhang et al., 2016; Wang et al., 2012). These results do not agree with those presented by Wang et al. (2012), where the heavier the rainfall intensity, the higher the rock fragment cover requirement for reducing soil erosion rates to negligible values.

\subsection{Sediment concentration}

Many authors reported that sediment yield decreases with increased rock fragment cover (Cerdá, 2001; Rieke-Zapp et al., 2007; Martínez-Zavala and Jordán, 2008; Wang et al., 2013). The positive effects of rock fragment cover on reducing sediment concentration may be explained mainly by its effects in protecting the soil surface from raindrop impact, raising the roughness of the surface soil, thereby increasing the consumption of flow energy and increasing the infiltration capacity, which leads to decreased soil loss as the number of rock fragments increases (Li et al., 2017).

\section{Conclusions}

In this study a field experiment was conducted in Central Chile, to study the effects of rainfall intensity and rock fragment cover on soil hydrological responses (Surface runoff, infiltration rate, soil erosion rate using the CAZALAC rainfall simulator. Results indicate that rock fragment cover contributed to delay the time to start surface runoff. Surface runoff tended to increase with rainfall intensity and decrease with percentage of rock fragment cover. For a given rainfall intensity and compare to bare soils, final infiltration rate increased directly proportional to the percentage of rock fragment cover. Rock fragments tended to reduce erosion rate and sediment concentration, but this positive effects were not proportional to rock fragment cover percentage. Even though the rainfall simulation with the CAZALAC took place at a relatively small area and under fixed experimental conditions, these conclusions may have implications for erosion modeling and guidance in the formulation and implementation of proper soil conservation plans for areas with similar characteristics in terms of soil and climate.

\section{References}

Baert, A. 2005. Evaluation of water erosion risks in drylands of Chile. Doctoral thesis, Gent University, The Netherlands. 144p.

Brakensiek, D.L., Rawls, W.J. 1994. Soil containing rock fragments: Effects on infiltration. Catena. 23, 99-110.

Casanova, M., Luzio, W., Maldonado, R. 2007. Correlación entre World Reference Base y Soil Taxonomy para los suelos de la VII Región del Maule de Chile. J. Soil Sci. Plant Nutr. 7, 14-21. 
Cerdá, A. 2001. Effects of rock fragment cover on soil infiltration, interrill runoff and erosion. European Journal of Soil Science. 52, 59-68.

Cerdá, A., González-Pelayo, Ó., Giménez-Morera, A., Jordán, A., Pereira, P., Novara, A., Brevik, E.C., Prosdocimi, M., Mahmoodabadi, M., Keesstra, S., Orenes, F.G., Ritsema, C.J. 2016. Use of barley straw residues to avoid high erosion and runoff rates on persimmon plantations in Eastern Spain under low frequency-high magnitude simulated rainfall events. Soil Research. 54, 154-165.

CIREN. 2010. Determinación de la erosión actual y potencial de Chile. CIREN, Santiago-Chile. 144p.

Constantz, J., Herkelrath, W., Murphy, J. 1988. Air encapsulation during infiltration. Soil Sci. Soc. Am. J. 52, 10-16.

Cousin, I., Nicoullaud, B., Coutadeur, C. 2003. Influence of rock fragments on the water retention and water percolation in a calcareous soil. Catena. 53, 97-114.

Da Rocha, P., Bhattarai, R., Alves-Fernandes, R., Prasanta Kumar, K., Vaz-Andrade, F. 2016. Soil surface roughness under tillage practices and its consequences for water and sediment losses. J. Soil Sci. Plant Nutr. 16, 1065-1074.

Dadkhah, M., Gifford, G.F. 1980. Influence of vegetation, rock cover and trampling on in- filtration rates and sediment production. Water Resour. Bull. 16, 979-986.

Ellies, A. 2000. Soil erosion and its control in Chile. Acta Geológica Hispana. 35, 279-284.

Li, T., He, B., Chen, Z., Zhang, Y., Liang, C. 2017. Effects of gravel on concentrated flow hydraulics and erosion in simulated landslide deposits. Catena. 156, 197-204.

Martínez-Mena, M., Abadia, R., Castillo, V., Albaladejo, J. 2001. Diseño experimental mediante lluvia simulada para el estudio de los cambios en la erosión del suelo durante la tormenta. Revista Cuaternario y Geomorfología. 15, 31-43.

Martínez-Zavala, L., Jordán, A. 2008. Effect of rock fragment cover on interrill soil erosion from bare soils in Western Andalusia, Spain. Soil Use and Management. 24, 108-117.

Martínez-Zavala, L., Jordán, A., Bellinfante, N., Gil, J. 2010. Relationships between rock fragment cover and soil hydrological response in a Mediterranean environment. Soil Science and Plant Nutrition. 56, 95-104.

Miller, F.T., Guthrie, R.L. 1984. Classification and distribution of soils containing rock fragments in the United States. In: J.D. Nichols, P.L. Brown and W.J. Grant (Ed), Erosion and Productivity of Soils Containing Rock Fragments. Soil Sci. Soc. Am. Spec. Publ. 13. 1-6.

Olivares, B., Verbist, K., Lobo, D., Vargas, R., Silva, O. 2011. Evaluation of the usle model to estimate water erosion in an alfisol. J. Soil Sci. Plant Nutr. 11, 72-85.

Poesen, J., Ingelmo-Sanchez, F., Mucher, H. 1990. The hydrological response of soil sur- faces to rainfall as affected by cover and position of rock fragments in the top layer. Earth Surface Processes and Landforms. 15, 653-671.

Poesen, J., Lavee, H. 1994. Rock fragments in top soils: significance and processes. Catena. 23, $1-28$.

Poesen, J., De Luna, E., Franca, A., Nachtergaele, J., Govers, G. 1999. Concentrated flow erosion rates as affected by rock fragment cover and initial soil moisture content. Catena. 36, 315-329.

Rieke-Zapp, D., Poesen, J., Nearing, M.A. 2007. Effects of rock fragments incorporated in the soil matrix on concentrated flow hydraulics and erosion. Earth Surface Processes and Landforms. 32, 1063-1076. 
Sangüesa, C., Arumi, J., Pizarro, R., Link, O. 2010. A Rainfall Simulator for the in situ Study of Superficial Runoff and Soil Erosion. Chilean J. Agric. Res. 70, 178-182.

Serrano-Muela, M.P., Nadal-Romero, E., Lana-Renault, N., González-Hidalgo, J.C., López-Moreno, J.I., Beguería, S., Sanjuan, Y., García-Ruiz, J.M. 2013. An exceptional rainfall event in the Central Western Pyrenees: spatial patterns in discharge and impact. Land Degradation and Development. 26, 249-262.

Sheridan, G.J., Noske, P.J., Lane, P.N.J., Sherwin, C.B. 2008. Using rainfall simulation and site measurements to predict annual interrill erodibility and phosphorus generation rates from unsealed forest roads: Validation against in-situ erosion measurements. Catena. 73, 49-62.

Van Wesemael, B., Poesen, J., de Figueiredo, T., Gerard, G. 1996. Surface roughness evo- lution of soils containing rock fragments. Earth Surface Processes and Landforms. 21, 399-411.

Verbist, K., Cornelis, W.M., Gabriels, D., Alaerts, K., Soto, G. 2009. Using an inverse modelling approach to evaluate the water retention in a simple water harvesting technique. Hydrology and Earth System Sciences. 13, 1979-1992.

Wang, X., Li, Z., Cai, C., Shi, Z., Xu, Q., Fu, Z., Guo, Z. 2012. Effects of rock fragment cover on hydrological response and soil loss from Regosols in a semi-humid environment in South-West China. Geomorphology. 151-152, 234-242.
Wang, X., Li, Z., Cai, C., Shi, Z., Xu, Q., Fu, Z., Guo, Z. 2013. Hydrological Response of Sloping Farmlands with Different Rock Fragment Covers in the Purple Soil Area of China. Journal of Hydrologic Engineering. 18, 446-456.

Yang, Z., Hao, H.M., Wang, D., Chang, X.F., Zhu, Y.J., Wu, G.L. 2015. Revegetation of artificial grassland improve soil organic and inorganic carbon and water of abandoned mine. J. Soil Sci. Plant Nutr. 15, 629-638.

Zhang, Y., Zhang, M., Niu, J., Li, H., Xiao, R., Zheng, H., Bech, J. 2016. Rock fragments and soil hydrological processes: Significance and progress. Catena. 147, 153-166.

Zhou, B., Shao, M., Wang, Q., Yang, T. 2011. Effects of different rock fragment contents and sizes on solute transport in soil columns. Vadose Zone J. 10, 386-393.

Ziadat, F.M., Taimeh, A.Y. 2013. Effect of Rainfall Intensity, Slope, Land Use and Antecedent Soil Moisture on Soil Erosion in an Arid Environment. Land Degradation and Development. 24, 582-590. 